\title{
De lokale staat
}

Citation for published version (APA):

Peters, K. (2014). De lokale staat. Maastricht University. https://doi.org/10.26481/spe.20140314kp

Document status and date:

Published: 14/03/2014

DOI:

10.26481/spe.20140314kp

Document Version:

Publisher's PDF, also known as Version of record

\section{Please check the document version of this publication:}

- A submitted manuscript is the version of the article upon submission and before peer-review. There can be important differences between the submitted version and the official published version of record.

People interested in the research are advised to contact the author for the final version of the publication, or visit the DOI to the publisher's website.

- The final author version and the galley proof are versions of the publication after peer review.

- The final published version features the final layout of the paper including the volume, issue and page numbers.

Link to publication

\footnotetext{
General rights rights.

- You may freely distribute the URL identifying the publication in the public portal. please follow below link for the End User Agreement:

www.umlib.nl/taverne-license

Take down policy

If you believe that this document breaches copyright please contact us at:

repository@maastrichtuniversity.nl

providing details and we will investigate your claim.
}

Copyright and moral rights for the publications made accessible in the public portal are retained by the authors and/or other copyright owners and it is a condition of accessing publications that users recognise and abide by the legal requirements associated with these

- Users may download and print one copy of any publication from the public portal for the purpose of private study or research.

- You may not further distribute the material or use it for any profit-making activity or commercial gain

If the publication is distributed under the terms of Article $25 \mathrm{fa}$ of the Dutch Copyright Act, indicated by the "Taverne" license above, 


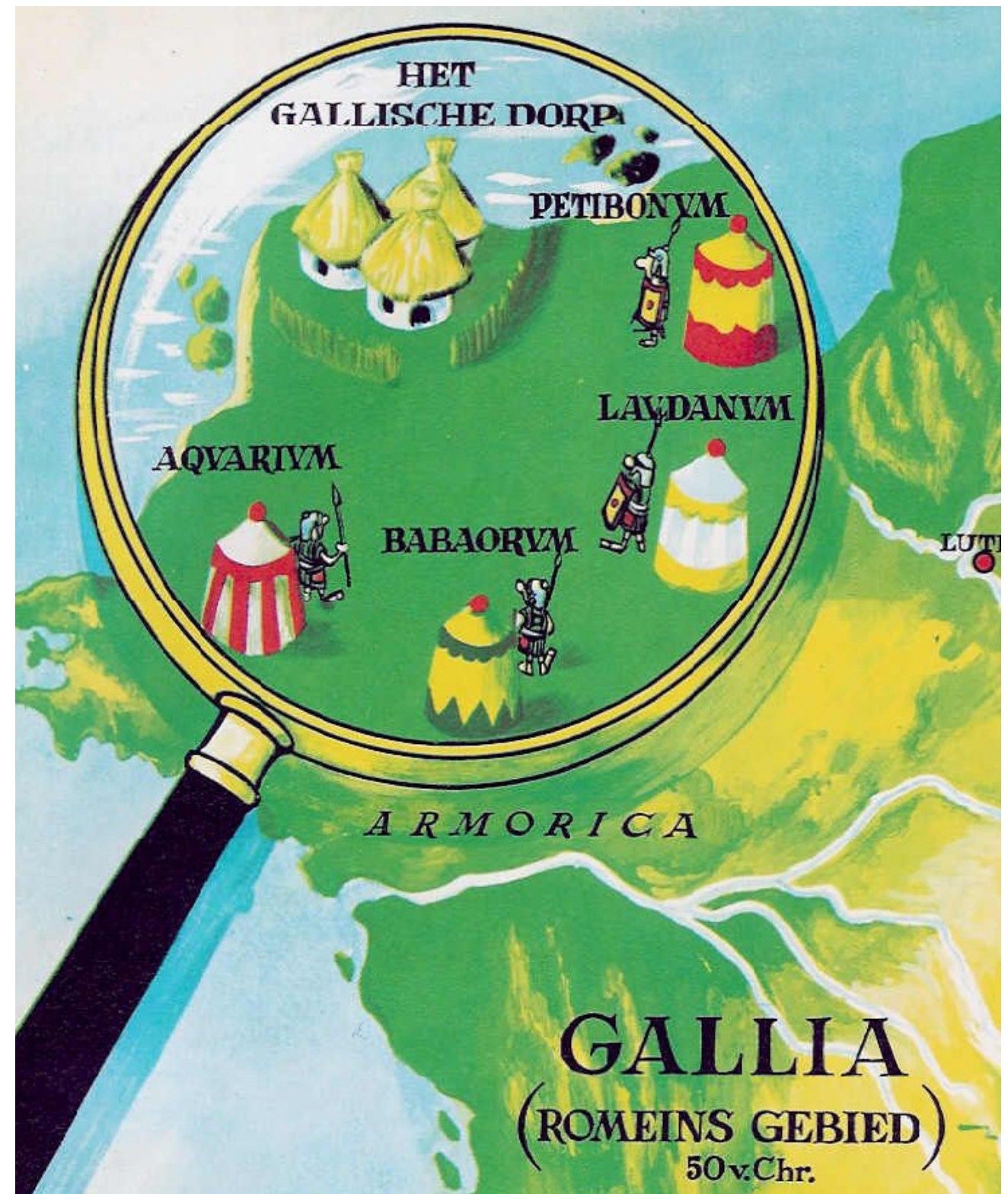

De lokale staat

Inaugurele rede

Prof. dr. Klaartje Peters 


\section{De lokale staat}

Rede zoals uitgesproken ter aanvaarding van de leerstoel Lokaal en regionaal bestuur aan de Faculteit der Maatschappij- en Cultuurwetenschappen, op 14 maart 2014

\section{Maastricht University}




\section{DE LOKALE STAAT}

Mijnheer de Rector Magnificus en Decaan van de Faculteit der Cultuur- en Maatschappijwetenschappen, gewaardeerde collega's, lieve familie en vrienden, geachte toehoorders,

Vorige maand kreeg ik dit krantenartikel onder ogen:

FrieschDagblad

Maandag 27 januari 2014

Vandaag 3

De macht verschuift naar de gemeente
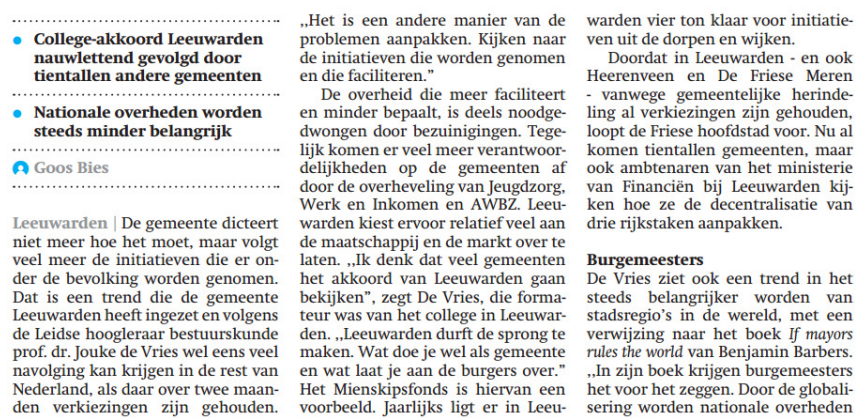

steeds minder belangrijker. Daarom derlandse Gemeenten (VNG) eerder verwacht ik ook krachtiger gemeen- deze maand pleitte. De Vries is daar tebesturen en vind ik het niet onwethouders heeft uitgebreid."

De decentralisatie van drie rijkstaken kan op termijn leiden to
méer decentralisaties. Dat hangt wel andelijk de belastingen natuurlijk wel omlaag. De belastingdruk moet
voor de burger niet groter worden."

作

ther een zorg, Werk en Inkomen en AWBZ zuljaarlijkse uitgave van zestien mil- len alle gemeenten de komende jaren in de commissie.Van Aartsen die gemeenten hun eicen lokale themass met het rapport De eerste overheid $\mathrm{Het}$ Friesch Daghlad vraagt de komende in 2007 deze machtsverschuiving twee maanden aan alle lijsttrekkers in naar de gemeenten in gang heeft ge- alle 21 Friese gemeenten waar op 19 ten meer mogelijkheden krijen om le speerpunt is en warrop ze als lokabelastingen te innen, zodat ze meer in de gemeente zouden bezuinigen speelruimte krijgen voor eigen be- Morgen begint de krant daarover een leid, waarvoor Annemarie Jorritsma, dagelijkse serie die een dag voor de

Het is een artikel uit het Friesch Dagblad, van 27 januari van dit jaar. ${ }^{1}$ Het bevat enkele highlights uit een gesprek dat deze krant voerde met Jouke de Vries, hoogleraar bestuurskunde aan de Universiteit Leiden.

Het interview met De Vries vond plaats naar aanleiding van zijn rol als formateur van het nieuwe college van Burgemeester en Wethouders van de gemeente Leeuwarden, dat enkele dagen eerder was aangetreden. Leeuwarden doet niet mee met de gemeenteraadsverkiezingen volgende week, maar hield vanwege een herindeling in november vorig jaar al verkiezingen.

In het interview verwijst De Vries onder meer naar het recent verschenen boek van de Amerikaanse politicoloog Benjamin Barber, getiteld 'If mayors ruled the world'. ${ }^{2}$

De Vries zegt: "In zijn (Barbers) boek krijgen burgemeesters het voor het zeggen. Door de globalisering worden nationale overheden steeds minder belangrijk. Daarom verwacht ik ook krachtiger gemeentebesturen en vind ik het niet onlogisch dat Leeuwarden het aantal wethouders heeft uitgebreid."

Precies een week later publiceerde NRC Handelsblad het volgende artikel: 


\section{Waarom stemmen? Gemeentepolitici zijn hun macht kwijt}
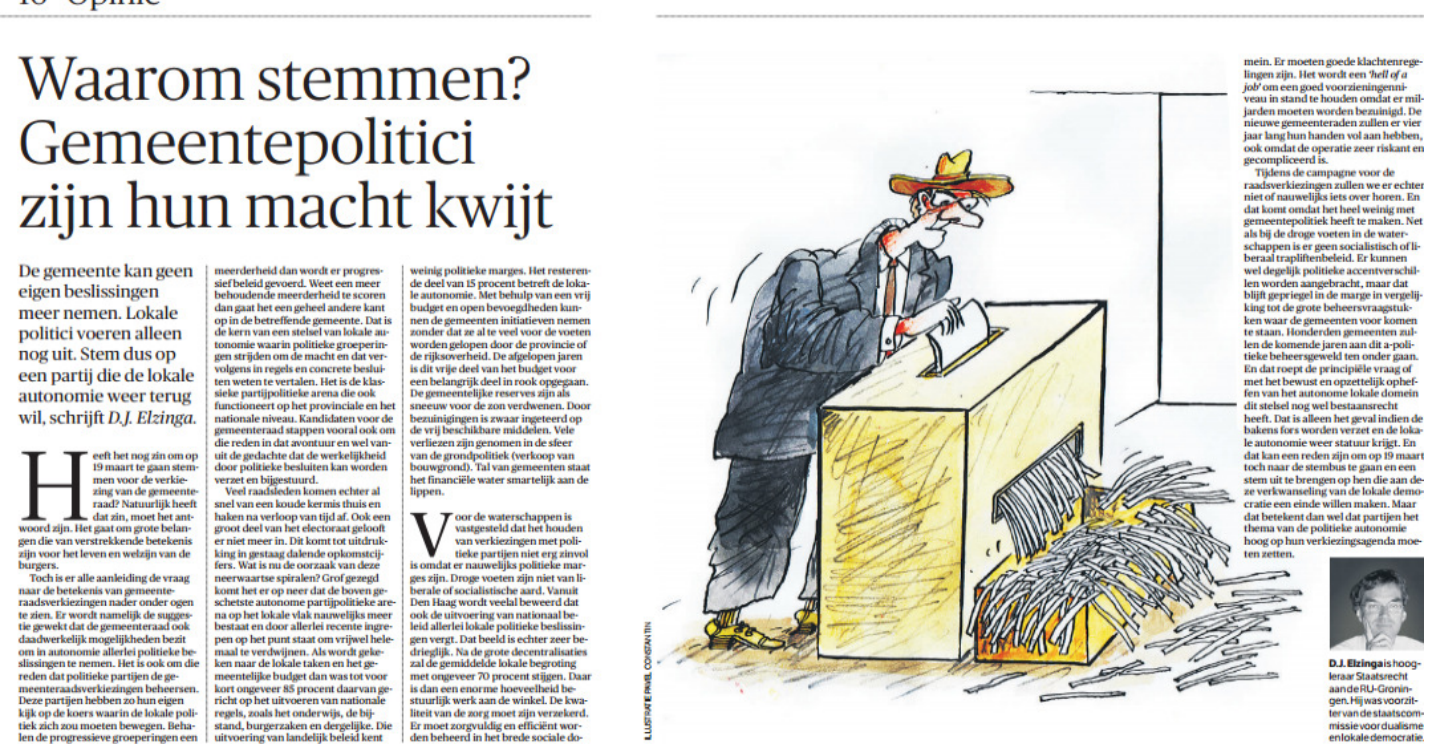

Het artikel is een ingezonden stuk van Douwe Jan Elzinga, hoogleraar staatsrecht in Groningen en grondlegger van de dualisering van het Nederlandse lokaal bestuur in 2002. Hij schetst in de NRC een heel ander beeld van het lokaal bestuur. Volgens Elzinga is het kleine beetje vrije beleidsruimte dat gemeenten nog hadden ten opzichte van de rijksoverheid, de laatste jaren voor een belangrijk deel in rook opgegaan. Hij schrijft: "Grof gezegd komt het er op neer dat de autonome partijpolitieke arena op het lokale vlak nauwelijks meer bestaat en door allerlei recente ingrepen op het punt staat om vrijwel helemaal te verdwijnen".

Ik was getroffen door het verschil tussen beide verhalen. De krantenkop boven het stuk bedenken ze niet zelf, zo weet ik uit ervaring, maar ook de inhoud van beide artikelen is volstrekt tegengesteld.

De gemeente wordt de komende jaren steeds belangrijker versus De gemeente doet er de komende jaren in het geheel niet meer toe.

De gemeente wordt belangrijker dan de rijksoverheid versus De gemeente wordt volledig door Den Haag gestuurd.

Dat kan niet allebei waar zijn.

De vergelijking roept vragen op: wie heeft er gelijk? En: hoe kan het dat twee kenners van het lokaal bestuur zo'n verschillend oordeel hebben? Wat weten we over het lokaal bestuur om te kunnen bepalen hoe het er voor staat, en in welke richting het zich ontwikkelt? 


\section{Inleiding}

In deze oratie wil ik wat dieper ingaan op deze vragen en laten zien hoe ik daarnaar kijk.

Het Nederlandse lokaal bestuur is daarmee het onderwerp van deze oratie. Dat Nederlandse lokaal bestuur ondergaat momenteel ingrijpende veranderingen, zoals niemand kan zijn ontgaan. In die zin is er zeker aanleiding om nu een praktijkleerstoel in te stellen.

In aanvulling op eerdere decentralisaties de afgelopen jaren hevelt de rijksoverheid de komende jaren in het sociale domein een substantieel takenpakket over naar de gemeenten. De 16 miljard euro waarmee dat gepaard gaat, vergroot het aandeel van de gemeenten in de totale publieke uitgaven in Nederland van een kwart tot ongeveer een derde. ${ }^{3}$ Dat is aanzienlijk, en de gevolgen ervan zullen groot zijn.

We gaan het hebben over Nederlandse gemeenten dus. Maar het lokaal bestuur - in het Engels local governance - omvat veel meer dan alleen de gemeente zelf. Het gaat om de besluitvorming en de uitvoering van beleid door alle betrokken partijen op lokaal niveau, en dat zijn er veel meer dan alleen de gemeente: het zijn bedrijven, burgers en verenigingen, professionele instellingen en maatschappelijke organisaties in de stad en in de regio, media in alle soorten en maten, maar ook andere gemeenten in de regio, de provinciale overheid, de rijksoverheid en zelfs Brussel: al die partijen spelen een rol in de lokale arena. Dat is kort samengevat de betekenis van local governance. Mijn blik is dus zeker niet alleen gericht op de processen die binnen het gemeentehuis plaatsvinden.

Terug naar de krantenkoppen. Ik vroeg mij zojuist af of we wel weten hoe het zit in het lokaal bestuur in Nederland. Wat zien we als we ernaar kijken?

Als je kijkt naar een bestuurlijk of politiek verschijnsel (of elk ander soort verschijnsel), doe je dat altijd vanuit een bepaald perspectief. Mijn perspectief is dat van een politieke wetenschapper. Dat zal u niet verbazen gezien mijn plek aan deze universiteit, bij het political science department van de Faculteit Cultuur- en Maatschappijwetenschappen. Ik kijk met een politiek-wetenschappelijke ofwel politicologische bril naar het lokaal bestuur.

Ik noem het een bril, omdat dat woord duidelijk maakt dat je met deze bril of dit perspectief bepaalde dingen beter ziet; en andere dingen misschien minder goed. Deze politiekwetenschappelijke bril vergroot het zicht op politieke processen.

En dan bedoel ik niet zozeer partijpolitiek - in de zin van wat politieke partijen doen -, maar politiek in de zin van verdelingsvraagstukken. Zoals de Amerikaanse politicoloog Laswell het in 1936 prachtig formuleerde: politiek gaat over de vraag 'Who gets what, when, how?'. ${ }^{4}$ Wie krijgt wat? Het is de bril die de belangen van deelnemers in politieke processen zichtbaar maakt, en daarmee ook de belangentegenstellingen en de belangenstrijd. Het is een bril die laat zien wie in de besluitvorming zijn zin krijgt, en wie niet. Mijn manier van kijken is in dit opzicht voorgoed beïnvloed door mijn promotieonderzoek, naar de machts- en invloedsverhoudingen in het Nederlandse openbaar bestuur. ${ }^{5}$

Het toepassen van dit politiek-wetenschappelijke perspectief op het lokaal bestuur levert niet alleen wetenschappelijke kennis op, maar ook - naar mijn stellige overtuiging - voor de praktijk 
bruikbare inzichten. Het leidt tot vragen die onderzoekers, analisten én deelnemers aan het openbaar bestuur zich zouden moeten stellen. Vragen over schuivende machtsverhoudingen en dominerende belangen. Dat is relevant, en zelfs nodig, omdat we daar nu vaak te weinig op gespitst zijn. Macht vraagt om tegenmacht, en die moet georganiseerd worden. Zeker omdat er steeds meer te halen is op het lokale speelveld de komende jaren. Er staat veel op het spel. Wie krijgt wat? 


\section{Thema 1: regionale samenwerking}

Om te laten zien wat we hebben aan dit politicologisch perspectief, geef ik een voorbeeld. Het betreft een onderwerp dat alle gemeenten momenteel sterk bezighoudt, namelijk dat van de gemeentelijke samenwerking ofwel regionale samenwerking.

Ik zal in deze oratie in totaal vier van dergelijke voorbeelden bespreken. Naast regionale samenwerking zijn dat:

- de relatie met maatschappelijke actoren,

- de relatie met burgers, en

- de relatie met andere bestuurslagen.

Het eerste voorbeeld is regionale samenwerking dus. Veel gemeentelijke taken, en zeker ook de nieuwe taken die er aankomen, worden door gemeenten in samenwerking met buurgemeenten uitgevoerd. Op dit moment zijn overal in Nederland gemeenten, klein én groot, bezig met de vormgeving van die deels verplichte samenwerkingsverbanden. ${ }^{6}$

Nou is er niks nieuws aan gemeentelijke samenwerking. Gemeenten hebben altijd al samengewerkt. ${ }^{7}$ Maar het is wel steeds meer geworden. ${ }^{8}$

In 2010 waren er zo'n 700 gemeentelijke samenwerkingsverbanden onder de Wet Gemeenschappelijke Regelingen, en daarnaast nog een veelvoud aan private verbanden, andere constructies en allerlei vormen van informele samenwerking. ${ }^{9}$ De gemiddelde gemeente werkt volgens ruwe schattingen in zo'n 30 verschillende verbanden samen met andere gemeenten. ${ }^{10} \mathrm{En}$ de komende jaren gaan dat er dus fors meer worden.

Samenwerking tussen gemeenten is een praktische oplossing voor een in zekere zin onoplosbaar probleem, namelijk dat er altijd taken of maatschappelijke opgaven zullen zijn, waarvoor de gemeentelijke schaal te klein is, en de provinciale schaal te groot. Door samenwerking ${ }^{11}$ te zoeken hoeven gemeenten die taken niet af te staan aan de provincie of het Rijk, of er grootscheeps voor te gaan fuseren, wat natuurlijk een hele toestand is. Zeker in dit land... ${ }^{12}$

Maar gemeentelijke samenwerking heeft ook serieuze nadelen. Daarover wordt al sinds jaar en dag gemopperd. Een argument dat daarbij vroeg of laat altijd de kop op steekt is dat van de gebrekkige democratische legitimatie.

De besluiten in samenwerkingsverbanden worden in de meeste gevallen namelijk genomen door een bestuur of orgaan van gemeentebestuurders uit de deelnemende gemeenten. De gemeenteraden van de deelnemende gemeenten kunnen hun eigen vertegenwoordiger in dat bestuur daarover ter verantwoording roepen, maar ze kunnen de genomen beslissingen niet sturen of terugdraaien. Omdat de gemeenteraden er dus feitelijk niet aan te pas komen, hebben kiezers uiteindelijk geen invloed. Dat brengt sommige mensen ertoe om ervoor te pleiten die samenwerkingsverbanden om te zetten in nieuwe, veel grotere gemeenten, zodat kiezers er tenminste weer directe invloed op hebben. Anderen opperen om over te gaan op direct gekozen regionale bestuurders. ${ }^{13}$ 
Maar het probleem van de democratische legitimatie van gemeentelijke samenwerking is niet in de eerste plaats een probleem van de kiezers. Die hebben in het lokaal bestuur sowieso niet veel directe invloed, althans in Nederland. Zij kunnen nu in feite ook alleen maar via de gemeenteraad invloed uitoefenen op de wijze waarop het college van burgemeester en wethouders de gemeente bestuurt. $^{14}$

Het probleem van de samenwerkingsverbanden raakt vooral het functioneren van de gemeenteraden. Die hebben door de toenemende samenwerking steeds minder greep op steeds meer terreinen van gemeentelijk beleid, steeds belangrijker terreinen bovendien. Dat zien degenen die er van buiten naar kijken ${ }^{15}$, en dat vinden veel raadsleden zelf ook.

\section{RAADSLID NU \\ NEDERLANDSE VERENIGING VOOR RAADSLEDEN}

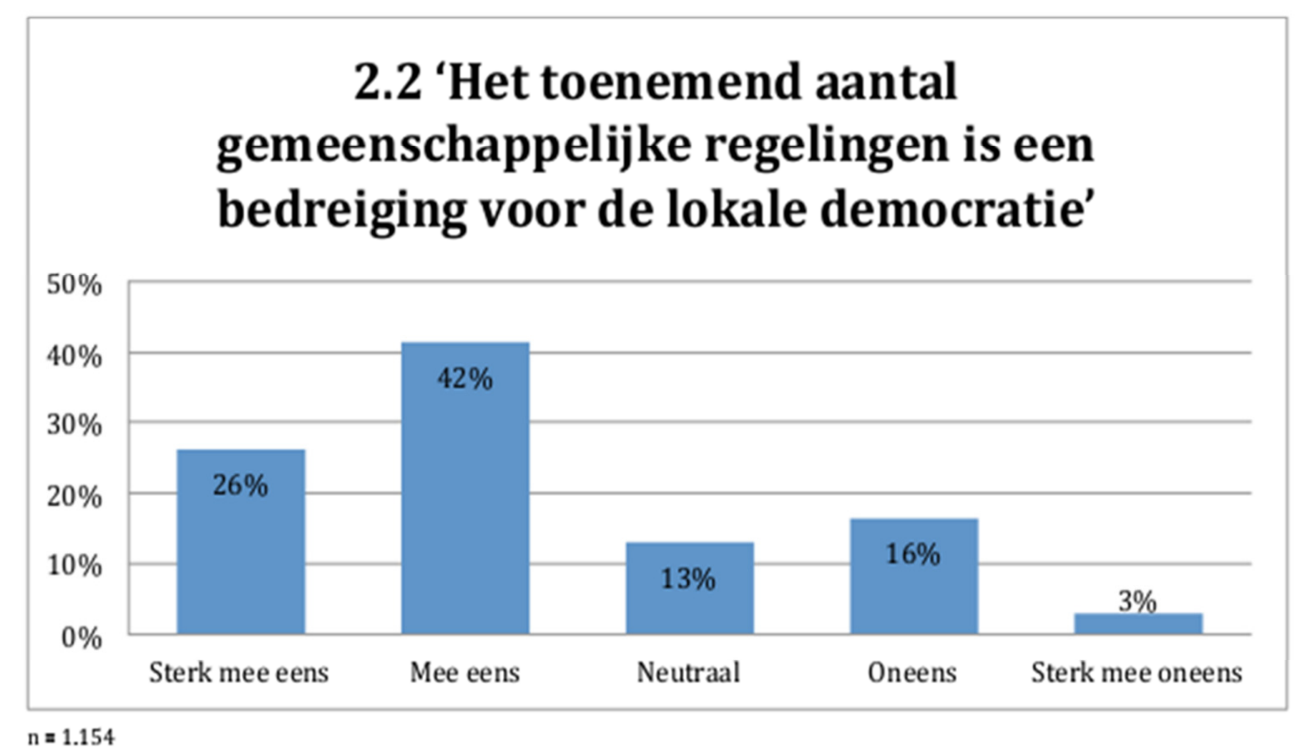

In deze grafiek uit een onderzoek van Raadslid.nu, de Nederlandse vereniging van raadsleden, ziet $u$ dat $68 \%$ van de zittende raadsleden het toenemend aantal gemeenschappelijke regelingen beschouwt als een bedreiging voor de lokale democratie. ${ }^{16}$

Dat beeld van het verlies van greep door gemeenteraden roept twee clusters van vragen op.

Allereerst is de vraag: is het waar dat raadsleden weinig invloed hebben op de besluitvorming in samenwerkingsverbanden? Hadden ze dat voorheen, dus voordat er werd samengewerkt, dan wel op de betreffende beleidsterreinen? En wat bedoelen we precies als we zeggen dat ze hun greep verliezen ${ }^{17}$ De geuite bezorgdheid over afnemende invloed van de raad gaat verder dan het ontbreken van formele bevoegdheden om beslissingen te kunnen nemen of corrigeren. Het heeft ook te maken met de veelheid aan samenwerkingsverbanden, op allerlei verschillende niveaus en 
met steeds andere partners, en vooral ook met de door raadsleden beleefde afstand tot het bovenlokale of regionale schaalniveau, waar de afwegingen nu worden gemaakt. ${ }^{18} 19$

De beslissingen die daar worden genomen onttrekken zich letterlijk aan hun gezichtsveld. Dat roept ook de vraag op in hoeverre dat in Amsterdam anders ligt dan in, zeg, Nederweert? Vragen die nader onderzoek waard zijn.

Overigens missen we sowieso een goed onderbouwd zicht op de invloed van de gemeenteraad in lokale besluitvormingsprocessen, en de ontwikkelingen daarin door de tijd. Dat geldt dus niet alleen in relatie tot de samenwerkingsverbanden. De meeste kenners van het lokaal bestuur zijn het erover eens dat de positie van gemeenteraden niet sterk is, en hun controlerende macht niet groot $^{20}$, ondanks allerlei formele instrumenten. ${ }^{21}$ Maar er zijn ook genoeg lokale bestuurders die vinden dat er niets aan de hand is. Ook hier zouden we graag beschikken over meer onderzoeksresultaten.

Terug naar de regionale samenwerking. De overeenstemming die er onder raadsleden en deskundigen bestaat roept ook een tweede vraag op. Als er sprake is van afnemende invloed van de gemeenteraad door meer regionale samenwerking - en daar komt het machtsperspectief van pas - dan roept dat de vraag op waar die invloed naartoe gaat. Dat regionale niveau is toch geen zwart gat, waarin invloed zonder meer verdwijnt? ${ }^{22}$ Aan wie of welke spelers verliest de raad invloed? Dat is een fascinerende vraag.

Zijn het de gemeentebestuurders, de wethouders en burgemeesters die in de regionale besturen zitten? Dat lijkt niet zonder meer het geval. ${ }^{23}$ In mijn ervaring voelen sommige gemeentebestuurders zich bijna net zo machteloos als hun gemeenteraad, als het aankomt op regionale besluitvorming. Je bent immers maar één van de velen, zeggen ze dan. Wat soms ook een gemakkelijk excuus is natuurlijk... Die machteloosheid geldt overigens niet voor grote steden. De stadsbestuurder heeft in het algemeen een heel andere positie in zo' $n$ bestuur dan zijn collegawethouders uit de kleine gemeenten. ${ }^{24}$ Vloeit alle invloed dus simpelweg naar de grote stad? Maar hoe zit dat dan als meerdere kleine gemeenten samenwerken?

Het kan ook zijn dat de ingewikkelde besluitvormingsstructuur waarmee veel bestuurlijke samenwerking gepaard gaat verhult dat veel invloed bij ambtenaren terecht komt. De ambtenaren die voor het samenwerkingsverband werken, of de samenwerkende ambtenaren van de deelnemende gemeenten. Ambtenaren zijn de drijvende krachten, hebben de kennis van zaken, bereiden besluitvorming voor en doen de uitvoering. Juist als bestuurders en politici het overzicht kwijt zijn, is er misschien ruimte voor ambtelijke machtsuitoefening, de vierde macht, die in stilte zijn werk doet en de zaken naar zijn hand zet. ${ }^{25}$ Of dat zo is, is niet duidelijk.

Is er überhaupt sprake van een vierde macht in het Nederlands lokaal bestuur? Daarover weten we veel minder dan over de macht van ambtenaren in de Haagse arena. ${ }^{26}{ }^{27}$ En hoe zit het met de politiek-ambtelijke machtsverhoudingen op lokaal niveau ? $^{28}$ Derksen en Schaap denken dat de wethouders machtiger zijn dan hun ambtenaren. ${ }^{29}$ Zou dat echt zo zijn? Dan werkt het op lokaal niveau toch anders dan in politiek Den Haag. ${ }^{30}$ We weten het niet, maar ik ben er wel nieuwsgierig naar. 


\section{Intermezzo: het machtsperspectief en het lokaal bestuur}

Het voorbeeld van de regionale samenwerking laat zien dat macht en invloed geen simpele begrippen zijn. Daar waar de één invloed verliest, is daar altijd een ander die wint? ${ }^{31}$ Of kan invloed ook verdampen of verdwijnen, bijvoorbeeld in een samenwerkingsverband?

Dit is niet de juiste plek voor een uitgebreide uiteenzetting over de begrippen macht en invloed. Zelf heb ik het altijd simpel proberen te houden door invloed te beschouwen als het waarneembare effect van het gebruik van macht. Macht heb je (of niet), en als je je macht gebruikt om je belang te realiseren, heb je invloed. Invloed hebben is, met andere woorden, je zin krijgen in concrete situaties of besluitvormingsprocessen, en dat valt te onderzoeken. ${ }^{32}$

In de Verenigde Staten ontstond in de jaren ' 50 en ' 60 van de vorige eeuw een bloeiende traditie van dit soort machtsonderzoek in steden, het zogenaamde community power onderzoek. ${ }^{33}$ Het zijn prachtige studies van besluitvormingsprocessen en netwerken van machtige mannen in Amerikaanse steden uit die tijd. ${ }^{34}$
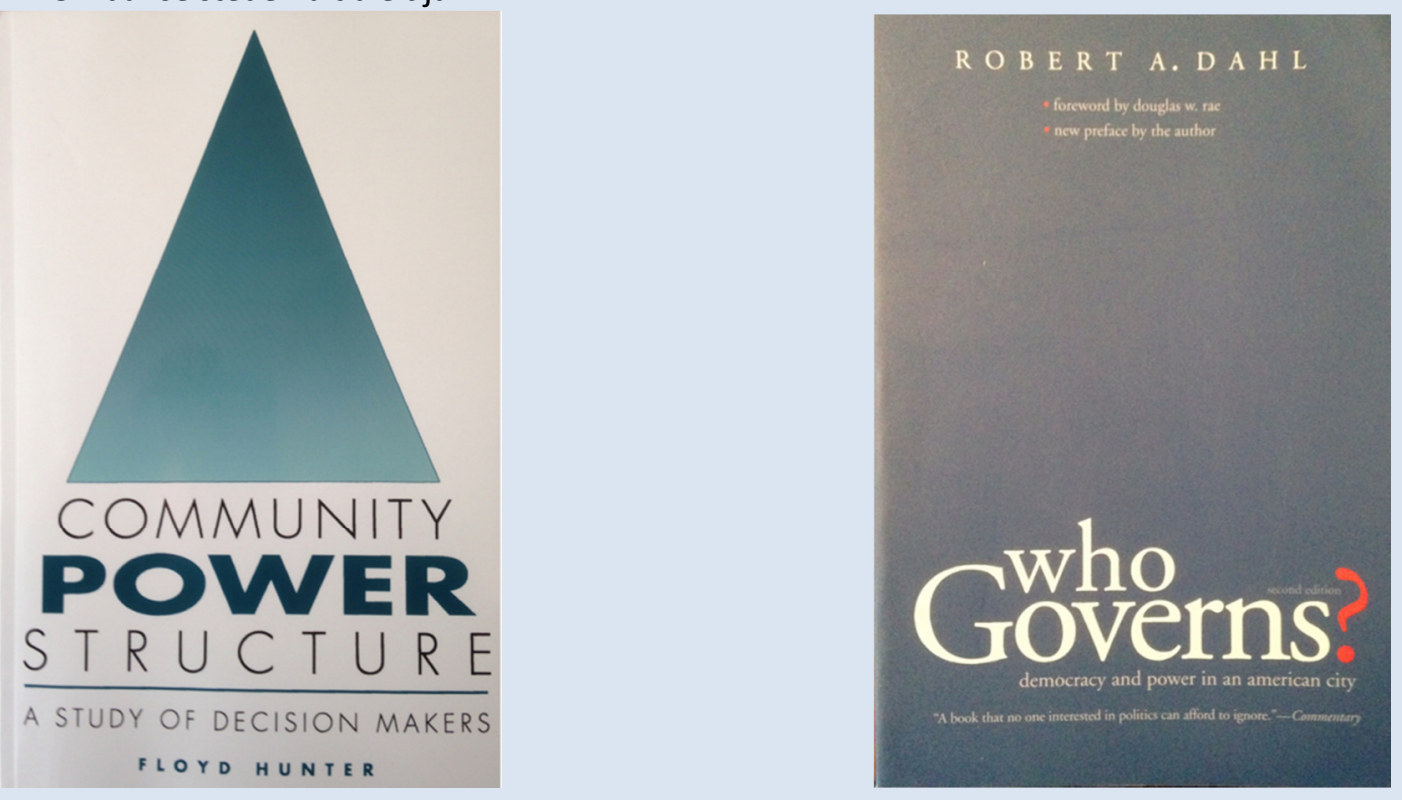

Het community power onderzoek is in andere landen echter nooit zo op gang gekomen als in de Verenigde Staten, en in de jaren '70 stierf de onderzoekstraditie ook daar een langzame dood ${ }^{35}$, door de felle methodologische, en in zekere zin ideologische debatten tussen de onderzoekers.

Het onderzoek naar urban politics, of lokale politiek, heeft zich sinds die tijd in andere richtingen ontwikkeld, hoewel macht en invloed nooit echt ver weg zijn. ${ }^{36}$

Ik pleit hier niet voor een revival van het community power onderzoek. Hoewel het idee om samen met studenten de komende jaren de verschillen in machtsverhoudingen onder de loep te nemen in steden hier in de grensregio, eigenlijk wel heel spannend is...

Maar het gaat me om de aandacht voor macht- en invloedsverhoudingen, en voor de (onderliggende) belangen die spelen in lokale besluitvormingsprocessen. Dat perspectief, het 
perspectief van de community power onderzoekers, wil ik de komende jaren hanteren bij het volgen van de ontwikkelingen in het lokaal bestuur. 


\section{Thema 2: relatie met maatschappelijke actoren}

Ik kom daarmee bij mijn tweede thema. Dat heeft betrekking op de rol van maatschappelijke actoren in het lokaal bestuur.

Behalve bestuurlijke samenwerking, met andere gemeenten, wordt er in het lokaal bestuur ook samengewerkt met ontelbare partijen buiten het stadhuis: maatschappelijke organisaties zoals scholen, corporaties en zorginstellingen, maar ook gewoon marktpartijen, grote en kleine bedrijven, en natuurlijk burgers, in verenigingen, buurtorganisaties etc.

Rondom dat stadhuis, of gemeentehuis, hebben zich netwerken gevormd, die bestaan uit partijen van binnen en buiten de overheid. Die netwerken en de relaties die de actoren in die netwerken met elkaar onderhouden, zijn meer dan een toevallige ontmoeting tussen overheid en buitenwereld. In deze beleidsnetwerken komt het beleid van de lokale overheid tot stand, wordt bepaald door wie en hoe het beleid wordt uitgevoerd; wordt gevolgd, gesproken en geoordeeld over hoe dat uitpakt, en ook bijgestuurd. In deze netwerken gebeurt het, zou je kunnen zeggen. Wat we weten over deze netwerken is dat ze per beleidsterrein verschillen. ${ }^{37}$ De organisaties die actief zijn op het ene terrein, zie je niet - of niet allemaal - terug op het andere terrein, hoewel bestuurders en ambtenaren natuurlijk overal meedoen.

Voor de meesten van u komt deze beschrijving niet als een verrassing. In de bestuurskunde wordt al enige decennia in termen van netwerken gesproken. ${ }^{38}$ Van government tot governance, heet dat dan. ${ }^{39}$ Kern van deze benadering is dat bestuur niet langer wordt bekeken vanuit het perspectief van de overheid die de samenleving van bovenaf bestuurt, maar dat we de blik richten op het geheel aan spelers dat meedoet, van binnen én buiten de overheid. De 'vermaatschappelijking' van het lokaal bestuur wordt dat dan ook vaak genoemd.

Veel van de hedendaagse netwerk- en governancestudies laten zien dat in steden, dorpen en wijken nieuwe vormen van samenwerking tussen overheid en maatschappelijke partijen ontstaan en dat daardoor maatschappelijke meerwaarde kan worden gecreëerd. ${ }^{40}$ Co-productie ${ }^{41}$ is de term die daarvoor ook wel wordt gebruikt.

Ik zou de stelling willen verdedigen dat het samenwerkingsperspectief in dat soort studies in sommige opzichten ook versluierend werkt. Het heeft weinig oog voor belangen van partijen, voor (soms) tegengestelde belangen bij de netwerkpartners ${ }^{42}$ en voor de vraag welke belangen structureel domineren. De machtsbril kan hier meerwaarde hebben.

Kijk maar eens naar wat er met de woningcorporaties in Nederland is gebeurd. Dat is een lang verhaal, maar een feit is dat een deel van de woningcorporaties zich sinds hun verzelfstandiging in de jaren '90 onvoldoende gelegen heeft laten liggen aan het publiek belang ${ }^{43}$, en zich is gaan richten op commercieel succes en eigen gewin. ${ }^{44}{ }^{45}$ Mijn punt is dat beleidsmakers in de afgelopen decennia vooral bezig lijken te zijn geweest met het kijken naar die nieuwe vormen van samenwerking, terwijl in de tussentijd niemand de corporaties goed in de gaten hield. 
De machtsbril gericht op het lokaal bestuur en externe partijen leidt daarom allereerst tot de empirische vraag: welke partijen hebben eigenlijk invloed in het lokaal bestuur? Het bestaan van verschillende netwerken op de verschillende beleidsterreinen suggereert dat de macht in het lokaal bestuur over heel veel verschillende partijen is verspreid en gespreid ${ }^{46}$, maar zeker weten doen we dat niet. Daartegenover staat dat je in een dorp of stad vaak steeds dezelfde mensen in steeds andere functies terugziet. Zit daar dan de werkelijke macht? ${ }^{47}$

En hoeveel invloed hebben die externe partijen eigenlijk? Is het beeld dat de gemeente hier en daar wat invloed afstaat, of is het andersom, en zetten machtige spelers feitelijk het lokaal bestuur naar hun hand $?^{48}$ Daarbij is het natuurlijk nodig om onderscheid te maken tussen verschillende typen partijen. Het is nogal een verschil of je het hebt over de lokale speeltuinvereniging, een grote regionaal opererende zorginstelling of een commerciële projectontwikkelaar. De vraag wie wie domineert is er één die niet vaak expliciet gesteld wordt in onze (nog steeds) op consensus gerichte bestuurscultuur, maar het is er wel één die gezien de forse uitbreiding van taken en budget op lokaal niveau zeker moet worden gesteld de komende jaren.

Als argeloze lezer zou je kunnen denken dat het in ieder geval duidelijk is in welke richting de macht zich beweegt. Het valt op dat in beschouwingen over het lokaal bestuur vaak wordt gesuggereerd dat er een verschuiving van macht van de overheid naar maatschappelijke partijen heeft plaatsgevonden, en dat de tijd dat de overheid in haar eentje bepaalde wat er gebeurde definitief voorbij is. ${ }^{49}$ Van government naar governance duidt dan niet meer op een verandering van kijken, maar op een feitelijke verandering in het bestuur. Hetzelfde geldt voor de term vermaatschappelijking van het bestuur. De term suggereert een ontwikkeling, van een bestuur dat méér dan voorheen in samenspraak met maatschappelijke partijen wordt bepaald.

Het machtsperspectief helpt om daar alert op te zijn. Het is namelijk de vraag in hoeverre dat klopt. $^{50}$ Ook vroeger waren maatschappelijke partijen actief in het bestuur van de lokale samenleving ${ }^{51}$, en er is altijd sprake geweest van verwevenheid met en beïnvloeding van de lokale overheid. $^{52}$ De governance-benadering heeft die relatie vooral zichtbaar gemaakt. Maar of er de latste jaren sprake is van meer invloed van maatschappelijke partijen is dus de vraag. De Vries niet Jouke de Vries dit keer, maar Michiel de Vries - stelt op basis van kwantitatieve data in $\mathbf{3 0}$ gemeenten dat er geen empirisch bewijs is dat de lokale overheid externe partijen meer dan voorheen bij de besluitvorming betrekt. $^{53}$ Hij beschouwt het gepraat over dergelijke ontwikkelingen dan ook vooral als wensdenken.

Maar goed... Los van de vraag hoe het vroeger was, is er tegenwoordig breed gedeelde overeenstemming dat de lokale overheid beleid niet in haar eentje bepaalt, maar haar macht deelt met vele andere partijen.

Voor de komende jaren willen we weten waar dat toe leidt. Vragen over de feitelijke invloed van private of maatschappelijke partijen gaan mij zeker bezighouden, vooral ook in het sociale domein, waar de gemeenten er forse taken bij krijgen.

Tijdens een recent symposium op de Vrije Universiteit werd gewaarschuwd hoe groot de veranderingen zijn in gemeenten. Eén van de topmensen van het $\mathrm{OM}$ zei daar: 'Het gaat om heel veel geld, schaarse expertise en branchevreemde activiteiten', en dat vond ik mooi uitgedrukt. ${ }^{54} \mathrm{Hij}$ 
zei het vooral vanwege de grote integriteitsrisico's die hij voorziet, maar wat mij betreft zijn er ook politiek-bestuurlijke risico's. Welke spelers gaan invloed verwerven, nu er op lokaal niveau veel op het spel staat? Kan de gemeente op tegen de grote marktpartijen, de instellingen, de nieuwe zorgondernemers, en ook de zorgverzekeraars? Welke belangen gaan worden gediend, wie houdt daar eigenlijk zicht op? Meer oog daarvoor, bij lokale bestuurders en gemeenteraden, is van belang. En ik kijk daarbij graag mee de komende tijd... 


\section{Thema 3: relatie met burgers}

Een derde thema dat ik wil bespreken betreft de relatie tussen burgers en hun lokaal bestuur.

Misschien had ik er wel mee moeten beginnen, met de burgers. Maar ik erger me eerlijk gezegd nogal eens aan de politieke correctheid tegenwoordig om rapporten over bestuur en politiek te beginnen met 'de burger ${ }^{55}$, terwijl deze - als je goed leest of luistert - eigenlijk helemaal niet serieus wordt genomen.

In dat verband kan ik het niet laten om hier kort iets te zeggen over de Nederlandse burgemeester. In een verhaal over machtsverhoudingen in het lokaal bestuur kan 'de baas van de gemeente' immers niet ontbreken.

'De baas van de gemeente'. Dat is hoe de meeste burgers naar de burgemeester kijken. ${ }^{56}$ Maar de burgemeester is in de Nederlandse verhoudingen zeker niet de baas van de gemeente. Ooit was hij dat wel. In het vooroorlogse NL was de burgemeester een echte regent. In de Gemeentewet stond dat de wethouders de burgemeester moesten 'bijstaan'. ${ }^{57}$ Hij was overigens wel vooral een rijksfunctionaris toen, de belichaming van het gezag van de rijksoverheid in de gemeente. Maar wél de baas.

$\mathrm{Na}$ de Tweede Wereldoorlog werd de burgemeester steeds meer een manager van het gemeentebestuur, die als grote voortrekker van college en raad probeerde grote bedrijven voor de stad te verkrijgen of te behouden, en die naoorlogse nieuwbouwwijken uit de grond liet stampen. ${ }^{58}$ Kortom: een echte leider, zouden we in hedendaags jargon zeggen.

Maar vanaf eind jaren '60 veranderde dat volledig. ${ }^{59}$ Het bestuur in Nederland, ook het lokaal bestuur, politiseerde in sterke mate, en wethouders namen de macht over. Dat had grote gevolgen voor de burgemeester: een leider was hij absoluut niet meer. En dat is zo tot de dag van vandaag.

De laatste jaren wordt die relatief zwakke positie van de burgemeester in toenemende mate als een probleem ervaren. ${ }^{60}$ In de steden is dit het meest voelbaar. De discrepantie tussen zijn feitelijke positie en de verwachtingen van de buitenwereld breekt hem op. Burgers en media verwachten krachtig leiderschap - of het nou gaat om weggepeste homostellen, veiligheid op straat of omdat het crisistijd is -, maar de burgemeester heeft veelal niet de positie om die verwachtingen waar te maken. ${ }^{61}$

De hamvraag is natuurlijk: hoe moet dat verder?

Voor- én tegenstanders van de gekozen burgemeester zijn het er in ieder geval over eens dat de aanstellingswijze van de burgemeester sterk bepalend is voor zijn positie en functioneren. ${ }^{62} \mathrm{Nu}$ is hij nog benoemd door de regering, maar wel voorgedragen door de gemeenteraad. Straks misschien gekozen, door de raad of door de inwoners van de gemeente.

Zelf denk ik dat je, zeker in de steden, op termijn niet ontkomt aan échte burgemeestersverkiezingen. ${ }^{63}$ Wat we nu hebben is dat in ieder geval niet. De huidige gang van 
zaken wordt soms beschreven als verkiezing door de gemeenteraad, maar met een verkiezing heeft het niks te maken. Het is een gewone sollicitatieprocedure, met alle geheimhouding en vriendjespolitiek die nu eenmaal bij sollicitatieprocedures horen.

Ik bedoel een echte verkiezing, waarbij burgemeesterskandidaten hun ambities voor de toekomst van een stad uitspreken, en daar ook door kiezers op worden beoordeeld en afgerekend. Dat is voor veel politicologen immers de kern van een democratie: je bestuurders kunnen kiezen en vooral ook weer kunnen wegsturen.

Zo'n verkiezing kan op twee manieren: rechtstreeks door de inwoners, of anders door de raad. Voor beiden is iets te zeggen. In dat laatste geval wijs ik graag op het mooie systeem bij onze zuiderburen (en ook in sommige andere Europese landen), waar de lijsttrekkers van de politieke partijen de burgemeesterskandidaten zijn. De gemeenteraadsverkiezingen zijn daardoor echte verkiezingen, het gaat om de macht om als nieuwe leider je agenda te kunnen uitvoeren, de 'strijd om de sjerp', zoals dat daar heet. Mooi, vind ik dat.

Maar wat ik vind doet er minder toe dan wat iedereen die goed kijkt nu ziet gebeuren: er hangt verandering in de lucht op dit punt (en echt niet alleen omdat CDA-leider Buma óm is).

Stel je voor dat het ervan komt ooit, die burgemeestersverkiezingen. Dat gaat de verhoudingen, de machtsverhoudingen, in het lokaal bestuur volledig op zijn kop zetten. Teveel om te kunnen voorspellen, en zeker teveel voor deze oratie. Maar nieuwsgierig maakt het wel!

\section{Burgers}

Terug naar de burgers. Ik schuif de burger als kiezer nu even terzijde, en richt me op de burger als participant.

Al tientallen jaren gaat het daarover, de relatie tussen burger en overheid, in steeds nieuwe termen. Van inspraak in de jaren '70, via interactieve beleidsvorming, naar burgerparticipatie, doedemocratie $^{64}$ en sinds kort burgerkracht. ${ }^{65}$ Daarbij gaat het vaak om het lokaal bestuur. Want als het ergens gebeurt, dan is het in het lokaal bestuur. Daar zijn de relaties tussen overheid en burger immers het meest direct.

De discussie over actief burgerschap in Nederland werd in september vorig jaar plotseling even verbreed, met de uitspraak in de Troonrede over de participatiesamenleving.

"Het is onmiskenbaar"... zei de regering bij monde van de koning, "dat mensen in onze huidige netwerk- en informatiesamenleving mondiger en zelfstandiger zijn dan vroeger. Gecombineerd met de noodzaak om het tekort van de overheid terug te dringen, leidt dit ertoe dat de klassieke verzorgingsstaat langzaam maar zeker verandert in een participatiesamenleving."

Het zal het kabinet waarschijnlijk verbaasd hebben, de ophef over deze zin. Beleidsmakers in Den Haag praten immers al jaren over meer eigen verantwoordelijkheid en zelfredzaamheid, en in wetten als de WMO en de Wet werk en bijstand zijn deze principes de afgelopen jaren ook wel degelijk zichtbaar geworden. Maar blijkbaar wordt het nu pas menens. 
Wat weten we eigenlijk over die vermeende ontwikkeling in de richting van een participatiesamenleving?

Het lastige is dat dat een ideologisch zwaar beladen discussie is. Allereerst zijn er veel mensen die vinden dat de participatiesamenleving een verhulde term is voor een harteloze overheid die haar verantwoordelijkheid voor het welzijn van haar burgers probeert af te wentelen op diezelfde burgers. Dat maakt de discussie natuurlijk beladen. Het feit dat in de Troonrede de participatiesamenleving in één adem - letterlijk - met het overheidstekort werd genoemd, draagt daar natuurlijk ook aan bij.

Maar ook als wetenschappers zich met de relatie overheid-burgers bezighouden is er soms sprake van ideologie. Diegenen die erover schrijven, vinden vaak ook dat die relatie anders zou moeten worden. ${ }^{66}$ Ik laat de term participatiesamenleving dan maar even voor wat ie is, en noem ze de pleitbezorgers van meer burgerparticipatie, of burgerbetrokkenheid. Ze willen dat het er is, en geloven erin, in burgerkracht, en het onderzoek is dus veelal gericht op best practices waar burgers ruimte hebben genomen en prachtige dingen voor elkaar hebben gekregen. ${ }^{67}$ En wie wil dat niet?

Maar het machtsperspectief - daar is het weer - laat zien dat de aandacht voor burgerparticipatie en burgerkracht in zekere zin afleidt van andere wezenlijke vragen over de invloed en zeggenschap van burgers. Want veel van die best practices waar we het steeds over hebben, zijn voorbeelden van wat het SCP 'zelfredzame burgerparticipatie' noemt. ${ }^{68}$ Het betreft veelal projecten die mensen zelf kunnen uitvoeren, zoals het beheer van kleinschalige voorzieningen in de buurt. Maar het betreft geen grote politieke vraagstukken waar de samenleving mee worstelt, zoals de verdeling van werk en inkomen, of de solidariteit in de gezondheidszorg. En het SCP waarschuwt dat meer zelfredzame participatie in de eigen omgeving op zich niet helpt tegen het door mensen ervaren tekort aan echte zeggenschap - het SCP noemt dat 'beleidsbeïnvloedende participatie' - over deze 'grootschalige vraagstukken'.69

De komende jaren gaat het in het lokaal bestuur echter wel degelijk om 'grootschalige vraagstukken'. De welvaartsstaat wordt immers steeds meer een lokale welvaartsstaat. ${ }^{70}$ De verzorgingsstaat wordt steeds meer een 'verzorgingsstad'. ${ }^{71}$ De decentralisatie van taken die voorheen tot de kern van de welvaartsstaat behoorden gaat gepaard met klassieke verdelingsvraagstukken, die daarmee ook naar het lokaal bestuur worden geschoven. Krijgen mensen straks van de gemeente de hulp die ze nodig hebben? Wie bepaalt wat mensen nodig hebben? Welke doelgroepen worden gehoord, en welke niet? Wie maakt de afwegingen, zeker als er straks onvoldoende geld beschikbaar is om noodzakelijke zorg én verworven rechten te blijven betalen? Dat zijn zaken die gaan spelen de komende tijd, en die we in de gaten moeten (willen) houden.

Daarnaast - en dat is een laatste aspect van de relatie overheid-burgers dat ik wil aanstippen - is het razend interessant om een ander soort burgerparticipatie in de gaten te houden. Eigenlijk, als je goed kijkt, is het geen participatie, het gaat verder dan dat. Participatie veronderstelt deelnemen aan iets, samen met anderen, maar je ziet steeds vaker voorbeelden van burgers die het letterlijk 'op eigen kracht doen'. Zonder de overheid, buiten de overheid om. In het blad Binnenlands Bestuur trof ik het afgelopen jaar minstens vier voorbeelden van dit soort initiatieven aan, en ik 
kom ze in de lokale praktijk soms ook tegen, initiatieven die een onderzoeker met machtsperspectief fascineren.

Het mooiste voorbeeld was dat van het dorp Keppel, onderdeel van de gemeente Bronckhorst in de Achterhoek. ${ }^{72}$ De inwoners hebben daar de dorpsschool opgekocht, die door henzelf wordt geëxploiteerd, en overwegen dat ook met het plaatselijk zwembad en de sporthal te doen. Die inwoners, veelal hoogopgeleide burgers natuurlijk, vinden dat de gemeente niet genoeg voor hen doet, en dus hebben ze de zaak in eigen hand genomen. Ze runnen zélf de tent en hebben het gemeentebestuur niet meer nodig. Ze doorkruisen zelfs het beleid van de gemeente, die moet toekijken hoe de zorgvuldig bedachte spreiding van voorzieningen over de hele gemeente in gevaar komt. En de directeur van de scholenkoepel zegt: "Onder het mom van burgerschap gebeuren hier dingen die absoluut niet door de beugel kunnen". ${ }^{73}$ Mooie quote. Dat is nog eens burgermacht. ${ }^{74}$ Maar wat moet je ermee, als overheid?

\section{Vrijstaat} Keppel
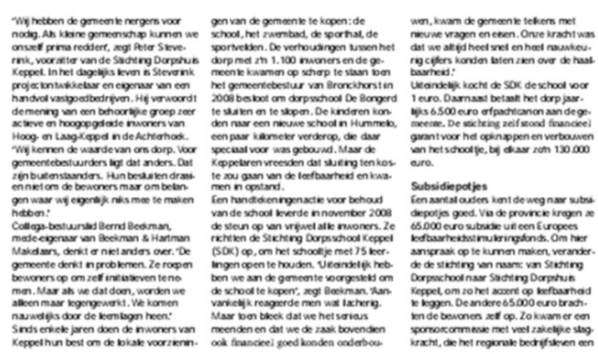

BURGERINITIATIEF > De dorpsschool wegbezuinigen? Geen sprake van.
Inwoners van Hoog. en Laag-Keppel nemen de lokale voorzien ingen Inwoners van Hoog. en Laag-Keppel nemen de lokale voorzien ing zichzelf als de enige partij met rechten. Het dorp is van hen.

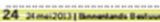

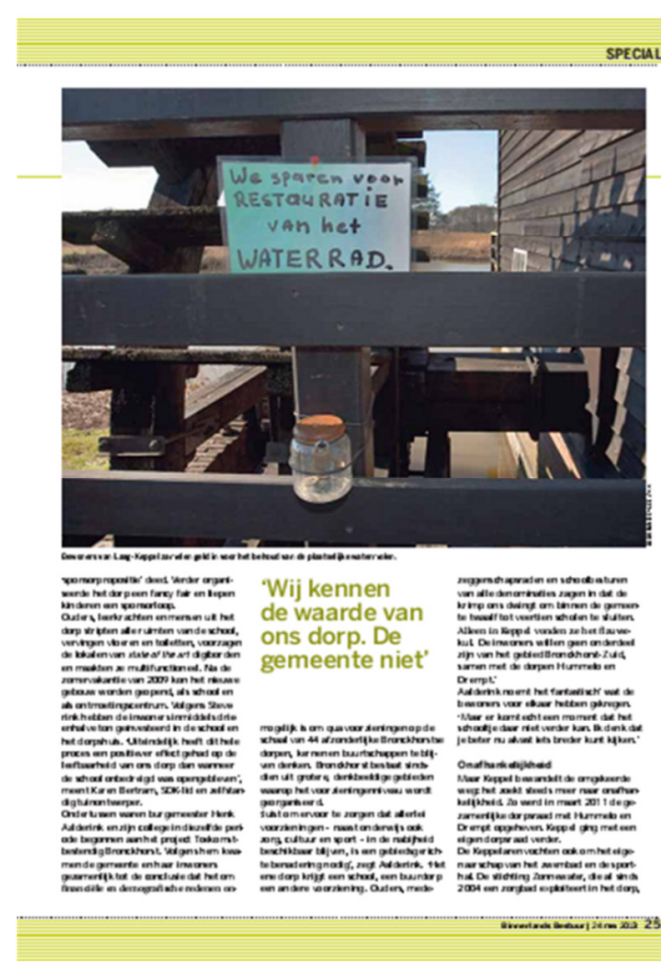




\section{Thema 4: relatie met andere bestuurslagen}

Ik kom bij het vierde en laatste thema waarop ik het machtsperspectief wil loslaten. Dat zijn de verhoudingen tussen het lokaal bestuur en de andere bestuurslagen.

Over de provinciale bestuurslaag ga ik het vandaag niet hebben. Sommigen van u zullen denken: daar heeft ze ook wel genoeg over gezegd. ${ }^{75}$ Dat is de vraag, maar voor nu laat ik het hier wel bij.

Voordat ik toe kom aan de relatie met de landelijke overheid, wil ik kort iets zeggen over Europa. Aan deze universiteit, en zeker ook in mijn faculteit, is het Europese perspectief altijd zeer aanwezig geweest. Dat heeft te maken met de ligging: in een uithoek van Nederland, maar in het hart van Europa. Althans, dat zegt iedereen dan. Maar het was ook gewoon een vroegtijdig besef dat de vorming en uitbouw van de Europese Unie niet enkel een extra bestuurslaag bovenop de nationale overheden is, maar dat het bestuur ván en ín de lidstaten er ingrijpend door werd veranderd. ${ }^{76}$ De nieuwe patronen van besluitvorming en interactie tussen de verschillende bestuurslagen, van Brussel tot aan het lokaal bestuur, werden onder de noemer van multi-level governance onderwerp van theorievorming en empirisch onderzoek, hier en ook elders in Europa.

De veranderingen in het lokaal bestuur, aan deze en de andere kant van de grens, in Duitsland en België, zijn ook een prachtig onderwerp om samen met de studenten in te duiken. Op dit moment onderzoekt een groep master-studenten de effecten van de grensoverschrijdende samenwerking hier in de Euregio. En de komende jaren is er nog veel meer mogelijk. Ik ben enthousiast over het zgn. research based learning zoals we dat aan deze universiteit kennen, en heb er hier - en overigens ook elders - mooie voorbeelden van gezien. Dat wil ik ook gaan doen de komende jaren.

Tot slot kom ik terug bij het voorbeeld waarmee ik deze openbare les begon, met de twee krantenkoppen. Het gaat hier om een cruciaal thema, de verhoudingen, de machtsverhoudingen, tussen de rijksoverheid en gemeenten. ${ }^{77}$

Het voorbeeld liet zien dat er blijkbaar onzekerheid bestaat over de vraag hoe die verhoudingen er over 10 of 15 jaar uitzien, en in welke richting ze zich dan hebben ontwikkeld. Daarbij zijn er grofweg twee redeneringen mogelijk.

De eerste wordt verbeeld door de krantenkop van De Vries: de macht verschuift naar de gemeente.

Het idee is dat met de overheveling van omvangrijke en voor burgers belangrijke taken goede kansen voor gemeenten ontstaan om aan betekenis te winnen, ten opzichte van de rijksoverheid. Het gaat immers om taken die - ik zei het eerder al - heel politiek zijn, of in ieder geval kunnen zijn. Gemeentebestuurders kunnen, en moeten misschien wel, zorgen dat hun inwoners zich daar bewust van worden, bewust van de belangrijke politieke afwegingen die er in de toekomst op lokaal niveau moeten worden gemaakt. Dat kan een forse impuls zijn voor de lokale democratie ${ }^{78}$, en van de gemeente misschien daadwerkelijk de 'eerste overheid' maken, om de titel van een VNG-rapport van enkele jaren geleden aan te halen. ${ }^{79}$ 
Daartegenover staat Elzinga - en hij is zeker niet de enige ${ }^{80}$ - met zijn bezorgdheid over de dominantie van Den Haag. Is er binnen de door de rijksoverheid gestelde beleidskaders en met de bij voorbaat te krappe budgetten überhaupt wel ruimte voor gemeenten om lokale keuzes te maken? Of zijn gemeenten gedoemd uitvoeringskantoren van de rijksoverheid te blijven?

We kunnen niet in de toekomst kijken. Maar wat we wel kunnen, althans zouden moeten kunnen, is zeggen hoe het er in het heden voor staat. De vraag naar de onderlinge machtsverhoudingen tussen rijksoverheid en gemeenten kan worden vertaald in de vraag hoeveel beleidsvrijheid of autonomie gemeenten feitelijk hebben. Dat blijkt een vraag die verrassend lastig te beantwoorden is. $^{81} 82$

We kunnen er wel wat over zeggen. We kunnen zeggen dat de Grondwet de lokale overheid autonomie garandeert, maar helaas niet hoeveel..$^{83}$ We kunnen ook de gevolgen van bepaalde ingrepen of ontwikkelingen duiden. Zo is er in de financiële verhoudingen tussen Rijk en gemeenten de afgelopen jaren het één en ander ten nadele van de lokale autonomie veranderd, bijvoorbeeld doordat de algemene uitkering uit het Gemeentefonds langzaam maar zeker toch niet zo algemeen meer is, en dus niet meer vrij besteedbaar door gemeenten. ${ }^{84}$ En we kunnen ook een vergelijking maken met het lokaal bestuur in andere landen - zo goed en zo kwaad als dat gaat - en dan bijvoorbeeld vaststellen dat ze ' $t$ in het Engelse lokaal bestuur nog veel moeilijker hebben, maar dat de Scandinavische gemeenten daarentegen onze jaloezie opwekken. ${ }^{85}$

Dat is het heden. De grote vraag is natuurlijk wat de eerdergenoemde decentralisaties gaan betekenen voor de autonomie van gemeenten de komende jaren.

En ook daar scherpt het machtsperspectief onze blik. Want een interessante vraag is of de rijksoverheid daadwerkelijk macht gaat afstaan aan het lokaal bestuur. Taken overhevelen is één ding, maar gunt politiek Den Haag de gemeenten straks de ruimte om zelf te bepalen hoe het moet, ook als dat betekent dat er verschillen tussen gemeenten gaan ontstaan? Gaan de ministeries daadwerkelijk inleveren, in termen van bemoeienis met de betreffende beleidsterreinen, en dus ook - bijvoorbeeld - in termen van het aantal beleidsambtenaren ${ }^{86}$ En wat zijn de gevolgen als het georganiseerd middenveld en de landelijke koepels Den Haag gaan verruilen voor de gemeenten? Om te lobbyen en zaken te doen (over beleid, over geld) moeten al die partijen de komende jaren immers steeds vaker bij de gemeenten aankloppen. Gaat dat ook gebeuren, en wat betekent dat voor de positie van de rijksoverheid? Dat zijn allemaal boeiende vragen die zich lenen voor onderzoek de komende jaren.

Heel concreet is ook de uiterst belangrijke vraag wanneer de landelijke politiek bereid zal zijn onder ogen te zien dat je gemeenten niet kunt belasten met steeds meer belangrijke taken en objectief veel te weinig middelen, zonder ze de mogelijkheid te geven hun eigen inkomsten te genereren. Belastinginkomsten bedoel ik dan natuurlijk. Mooie woorden over lokaal maatwerk en lokale keuzes betekenen immers ook dat in de lokale arena moet kunnen worden besloten over, bijvoorbeeld, hogere belastingen, om een door de lokale gemeenschap gewenst voorzieningenniveau in stand te houden. 
De terughoudendheid in politiek Den Haag om gemeenten in staat te stellen meer eigen belastingen te heffen, is op de lange termijn niet meer houdbaar, maar wel begrijpelijk. ${ }^{87}$ Meer belastingheffing door gemeenten kan in feite alleen onder gelijktijdige verlaging van de rijksbelastingen. Dat is nog eens macht uit handen geven. En dat zal dus ook nog wel even duren.

De strijd over wie daadwerkelijk de 'eerste overheid' is, is nog lang niet beslist.

De lokale staat ${ }^{88}$ zal voorlopig nog geen concurrent zijn voor de Nederlandse staat. Maar voor diegenen die aan de staatsvorming op lokaal niveau bijdragen, of er met een onderzoeksbril naar kijken, wordt het de komende tijd wel steeds spannender. 


\section{Dankwoord}

Aan het eind van deze oratie wil ik, tot slot, graag een aantal mensen bedanken.

Dat is allereerst het College van Bestuur van deze universiteit, en het bestuur van de Faculteit Cultuuren Maatschappijwetenschappen, in het bijzonder decaan Rein de Wilde, voor het in mij gestelde vertrouwen.

Ik bedank ook Sophie Vanhoonacker, Esther Versluis en mijn andere collega's voor het warme welkom in de faculteit en het political science department. Ik ben er nog maar kort, en één dag in de week is niet veel, maar ik verheug me op de toekomstige samenwerking en uitwisseling. Alleen al af en toe samen lunchen is een prettige afwisseling voor een zzp-er.

Ook de studenten zorgen altijd voor afwisseling, en niets is leuker dan te zien hoe sommigen van jullie lol krijgen in het zelf doen van onderzoek, het mooiste vak dat er is, wat mij betreft.

En er is aan deze universiteit nog een gezelschap dat ik dankbaar ben, en dat is het Universiteitskoor Maastricht. In 2004 was het koor voor mij als nieuwkomer in deze stad de start van mijn sociale leven, en in die zin is het nog steeds belangrijk. Maar gaandeweg heb ik gezien dat het koor ook belangrijk is voor de universiteit. Het is een geweldige vereniging, uniek in het bijeenbrengen van studenten én docenten, van buitenlanders én Nederlanders, en zelfs een enkele echte sjeng (Maastrichtenaar). Dirigent Wim Vluggen is verantwoordelijk voor de inwijding van vele generaties buitenlandse studenten in de Nederlandse taal, en daarmee ook de Nederlandse samenleving. Dat is voor de universiteit een groot goed.

Dan...als zelfstandig onderzoeker heb ik al tien jaar geen directe collega's, maar gelukkig wel veel mentoren, vakgenoten en vakvrienden, van wie ik veel heb geleerd, die ik altijd om raad kan vragen en met wie ik mijn hele leven hoop te kunnen doorpraten over de fascinerende wereld van politiek en bestuur. Ze zitten overal: in de wetenschap, in en om het openbaar bestuur en in de politiek.

Het zijn er teveel om hier op te noemen, maar een speciaal woord van dank is voor Marielle Verberk, Peter Castenmiller, Leo Huberts, Jouke de Vries, Gerard Schouw en Arno Korsten, en ook voor Joop van den Berg, Marcel van Dam, Marc Hertogh, Kirsten Veldhuijzen en Tonco Modderman. In dit rijtje passen ook mijn collega's in de Rekenkamer Maastricht, inclusief oud-voorzitter Mathijs Mennen, die ik wil bedanken voor de stevige en inspirerende discussies die wij al jaren voeren, over de vraag wat je van een gemeente kan en mag verwachten en wat wij daar als rekenkamer aan kunnen bijdragen.

Tot slot bedank ik mijn ouders, en dan houd ik op met praten. Hoewel zij allang weten dat dat nooit zal gebeuren... Papa en mama: hoewel jullie je de afgelopen jaren regelmatig hebben afgevraagd hoe het in godsnaam mogelijk is dat twee leraren kinderen hebben voortgebracht die ondernemer zijn geworden, sluit ik met deze 'openbare les' toch naadloos aan op de familietraditie, lijkt me.

Het allerlaatste woord is voor Jaap: dank je wel.

\section{lk heb gezegd.}


1 Geschreven door Goos Bies.

2 B. R. Barber (2013). If Mayors Ruled the World. Dysfunctional Nations, Rising Cities. New Haven \& London: Yale University Press.

3 Waarbij ik er maar even vanuit ga dat het vaakgenoemde bedrag van $€ 16$ miljard correct is (zie bijvoorbeeld het interview met Arno Visser, lid van de Algemene Rekenkamer, in het blad Binnenlands Bestuur in december 2013:

http://www.binnenlandsbestuur.nl/financien/nieuws/16-miljard-euro-raakt-uit-

zicht.9173079.lynkx). De berekening van de percentages is gebaseerd op: M.A. Allers, B. Steiner, C. Hoeben en J.B. Geertsema (2013). Gemeenten in perspectief. Groningen en Almere: COELO en Bruno Steiner Advies, pp. 20-21; en: M.C. Wassenaar, M.A. Allers en A.J.W.M. Verhagen (2014). Financiën van de decentrale overheden (tweede herziene druk). Den Haag: Sdu Uitgevers, p. 11.

4 H. D. Laswell (1936). Politics: Who gets What, When, How. New York: Mc Graw-Hill.

$5 \quad$ K. Peters (1999). Verdeelde macht. Een onderzoek naar invloed op rijksbesluitvorming in Nederland. Amsterdam: Boom.

6 Zie voor de laatste stand van zaken: Brief aan de Tweede Kamer van de minister van BZK over gemeentelijke samenwerkingsverbanden sociaal domein en ambassadeurs regionale samenwerking, 3 februari 2014.

7 Al in de Gemeentewet van 1851 is hierover een bepaling te vinden, zie: VNG (2008). Samenwerking tussen gemeenten op basis van de Wgr. Praktijkvoorbeelden, dilemma's en kansen. Den Haag, p. 13.

8 Zo is tussen 2005 en 2010 het aandeel van de intergemeentelijke uitgaven op het totaal van de gemeentelijke uitgaven gestegen van 6\% naar 14\% (SCP (2012). Maten voor gemeenten 2012. Prestaties en uitgaven van de lokale overheid in de periode 2005-2010. Den Haag, pp. 204-205).

9 In 2010 leidde een telling tot 698 publieke samenwerkingsverbanden, en meer dan 1000 private, zoals stichtingen en vennootschappen (Ministerie van BZK \& Berenschot (2010). Samenwerking tussen decentrale overheden: een nadere analyse van samenwerking op grond van gemeenschappelijke regelingen. Den Haag).

10 Dit is een vaak genoemd aantal, hoewel de bron niet te achterhalen is. Zie bijvoorbeeld: http://www.vngmagazine.nl/archief/1814/gideonsbende-cruciaal-voor-succes-gemeentelijkesamenwerking.

11 Zie onder meer: M. Herweijer en M.J. Fraanje (red.) (2011). Samen werken aan bestuurskracht. Intergemeentelijke samenwerking onderzocht. Alphen aan den Rijn: Kluwer.

12 De ingrijpende bestuurlijke hervormingen die een aantal jaren geleden in Denemarken plaatsvinden, gingen gepaard met een grootscheepse opschaling van gemeenten, die heel snel en soepel is verlopen. Zie onder meer: K. Peters (2012). A Window of Opportunity. Institutional Reform in Denmark, in: S. Cels, J. de Jong and F. Nauta (eds.) Agents of Change. Strategy and Tactics for Social Innovation. Brookings Institution Press and Ash Institute For Democratic Governance and Innovation of the Harvard Kennedy School of Government; J. Blom-Hansen (2012). Local government in Denmark and the 2007 municipal reform, in: A. Moisio (ed.) Rethinking local government: Essays on municipal reform, VATT Publications, Government Institute for Economic Research, Helsinki.

13 Zo heeft de bestuurskundige Korsten wel gepleit voor een regiogemeente met rechtstreeks gekozen bestuurders (A. Korsten (2009). Op naar een regiogemeente. De Limburger, 10 april). Een extra verkiezing erbij lijkt vooralsnog echter geen realistisch pleidooi, gezien de dalende opkomstcijfers voor bestaande verkiezingen, en met de opluchting over de afschaffing van de rechtstreekse waterschapverkiezingen nog vers in het geheugen.

14 Zie ook: W. Derksen (2014). Het grote misverstand van de lokale politiek. 4 maart: http://www.wimderksen.com/?p=52878.

15 Zie bijvoorbeeld de interviews met Tops, Elzinga, Peters en Boogers in: J. Loots en P.H. Peeters (2013). De gemeenteraad heeft geen toekomst. Waarom stemmen op 19 maart 2014?. Eindhoven: uitgeverij Pepijn.

16 In de enquête van januari 2014 van de Nederlandse vereniging voor raadsleden (Raadslid.nu) zegt $68 \%$ van de 1154 raadsleden het 'eens' of 'sterk eens' te zijn met de stelling dat het toenemend 
aantal gemeenschappelijke regelingen een bedreiging is voor de lokale democratie. Zie: http://www.raadslid.nu/sites/www.raadslid.nu/files/redactie/onderzoek onder raadsleden naa $r$ regionale samenwerking.pdf.

17 Dergelijk onderzoek ken ik eigenlijk niet. Er zijn wel enkele beperkte studies naar de beleving onder gemeenteraadsleden, zoals een onderzoek onder Rotterdamse raadsleden over de samenwerking in de stadsregio Rotterdam uit 2009. De raadsleden hebben het gevoel dat de besluitvorming zich hoofdzakelijk afspeelt binnen ambtelijke sferen en tussen beroepspolitici (lees burgemeesters en wethouders). (Stadsregio Rotterdam, De Aftrap: presentatie en verslag van startbijeenkomst op 18 maart 2009, zie:

http://www.bds.rotterdam.nl/Bestuurlijke Informatie:7/Raadsinformatie/Gemeenteraad 2006 2010/2009/Kwartaal_2/Raadsvergadering_van_11 juni_2009/Mededeling_van ingekomen_stuk ken 2009 week 18 t m 22/Overige brieven/V09GR1215 Van de Stadsregio Rotterdam Dial oog 2009 De Aftrap Presentatie en verslag van de startbijeenkomst op 18 maart 2009/09 GR1215a Van de Stadsregio Rotterdam Dialoog 2009 De Aftrap Presentatie en verslag van de startbijeenkomst op 18 maart 2009).

M. Boogers (2013). Het raadsel van de regio. Waarom regionale samenwerking soms resultaten oplevert. Oratie Universiteit Twente, p.38.

19 Die constatering zou betekenen dat de vluchtweg van de zgn. 'lichte samenwerkingsvormen', waarbij minder bevoegdheden worden afgestaan, waarschijnlijk geen oplossing biedt (zie onder meer: L. van den Dool en L. Schaap (2014) Intergemeentelijk samenwerken: het kan ook licht. Een verkenning van lichte vormen van intergemeentelijke samenwerking. Bestuurskunde, 23(1), 6575). Het probleem voor raadsleden lijkt immers voor een belangrijk deel te zitten in de ervaren afstand tussen de eigen gemeente en het (regionale) niveau waarop de afwegingen moeten worden gemaakt, en niet zozeer in de feitelijke bevoegdheden. Volgens andere bestuurskundigen is juist de vergaande vorm van ambtelijke integratie/fusie een oplossing om het democratisch tekort te verminderen (zie onder meer: M. Herweijer en M.J. Fraanje (red.) (2011). Samen werken aan bestuurskracht. Intergemeentelijke samenwerking onderzocht. Alphen aan den Rijn: Kluwer).

20 Zie voetnoot 14.

21 P. Castenmiller, M van Dam en K. Peters (2013). “...geven de raad alle informatie...”. Een onderzoek naar informatievoorziening aan de gemeenteraad. Den Haag: Stichting Decentraal Bestuur, in opdracht van het ministerie van BZK.

22 Krouwel noemt het 'een democratische Bermuda-driehoek, waarin alle controle en verantwoording verdwijnt' (A. Krouwel (2013). Ondermijnende samenwerking. VNG magazine, 12 december 2013, zie: http://www.vngmagazine.nl/weblog/15436/column-ondermijnendesamenwerking).

23 R. Prins e.a. (2012). Nationale wetten versus lokale besluiten. Een spanningsveld voor burgemeesters, onderzoek in opdracht van het ministerie van BZK. Rotterdam: Erasmus Universiteit.

24 Vergelijk: M. Boogers (2013). Het raadsel van de regio. Waarom regionale samenwerking soms resultaten oplevert. Oratie Universiteit Twente, p. 32.

25 R. Crince le Roy (1969). De Vierde Macht. Oratie Universiteit Utrecht; M.A.P. Bovens (2000). De Vierde Macht Revisited. Over ambtelijke macht en publieke verantwoording. Oratie Universiteit Utrecht; K. Peters (1999). Verdeelde macht. Een onderzoek naar invloed op rijksbesluitvorming in Nederland. Amsterdam: Boom.

26 Zie: K. Peters (1999). Verdeelde macht. Een onderzoek naar invloed op rijksbes/uitvorming in Nederland. Amsterdam: Boom; Bovens e.a. (2007). Openbaar bestuur ( $7^{\mathrm{e}}$ herziene druk). Alphen aan den Rijn: Kluwer, pp. 165-204.

27 Er zijn een paar stadsstudies waar de vraag min of meer expliciet aan de orde komt, maar het is te weinig, en deels te oud, om conclusies uit te trekken. Zo ziet Berveling in Amsterdam aanzienlijke verschillen in ambtelijke macht tussen de verschillende beleidsdomeinen, met een machtige ambtelijke dienst in met name het ruimtelijke domein (J. Berveling (1994). Het stempel op de besluitvorming. Macht, invloed en besluitvorming op twee Amsterdamse

Beleidsterreinen. Amsterdam: Thesis). Dat laatste sluit aan bij ouder onderzoek van Derksen (W. Derksen (1985). Macht in de gemeente; beleidsanalyse als vorm van machtsonderzoek. 
Amsterdam/Zwolle: Uitgeverij Kobra). Lelieveldt ziet in Zwolle een dominante as van bestuurders en ambtenaren waar elke maatschappelijke partij die wat van de gemeente wil lángs moet (H.T. Lelieveldt (1999). Wegen naar macht. Politieke participatie en toegang van het maatschappelijk middenveld op lokaal niveau. Amsterdam: Thela Thesis Publishers). En Boogers laat zien dat in drie Brabantse steden een enkele topambtenaar als zeer invloedrijk wordt beschouwd. (M. Boogers (2014). Pulling the Strings: An Analysis of Informal Local Power Structures in Three Dutch Cities. Local Government Studies, DOI: 10.1080/ 03003930.2013.841579, 9 January).

28 Is bijvoorbeeld een sterke bestuurder een voorwaarde voor sterke ambtenaren, zoals over de landelijke politiek vaak wordt gezegd (Peters, 1999), of werkt dat op lokaal niveau anders?

29 W. Derksen en L. Schaap (2010). Lokaal bestuur (zesde druk). Dordrecht: Convoy Uitgevers, p. 112.

30 K. Peters (1999). Verdeelde macht. Een onderzoek naar invloed op rijksbesluitvorming in Nederland. Amsterdam: Boom.

31 Vergelijk: M. Bovens e.a. (1995). De verplaatsing van de politiek. Amsterdam: Wiardi Beckman Stichting.

32 Zie Peters 1999 (voetnoot 30). In deze strikte definitie en de bijbehorende meetmethode van de intensieve procesanalyse kan invloed niet verdwijnen, voor alle duidelijkheid. Een beslissing is altijd door één of meerdere actoren beïnvloed. Als er geen interne of externe actoren zijn die de beslisser hebben beïnvloed, is het de beslisser zelf die alle invloed krijgt toegekend. Het zou zeker interessant zijn om te zien wat het toepassen van deze meetmethode op besluitvorming in regionale samenwerkingsverbanden zou opleveren.

33 Zie voor een beschrijving: A. Harding (2009). The History of Community Power, in: J. S. Davies and D. L. Imbroscio (eds.). Theories of Urban Politics (2nd edition). LA/London/New Delhi/Singapore /Washington DC: Sage Publications, pp. 27-39; K. Peters (1999). Verdeelde macht. Een onderzoek naar invloed op rijksbesluitvorming in Nederland. Amsterdam: Boom; J. Berveling (1994). Het stempel op de besluitvorming. Macht, invloed en besluitvorming op twee Amsterdamse beleidsterreinen. Amsterdam: Thesis.

34 De twee bekendste zijn: F. Hunter (1953). Community Power Structure. A Study of decision Makers. Chapel Hill: The University of North Carolina Press; R.A. Dahl (1961). Who Governs? Democracy and Power in an American City. New Haven: Yale University Press.

35 Zie bijvoorbeeld: Berveling 1994; Peters 1999; Harding 2009 (voetnoot 33).

36 Zie bijvoorbeeld in de urban regime theorie, die de blik richt op de dominante machtscoalitie in een stad (C. N. Stone (1989). Regime Politics. Lawrence: University Press of Kansas). In Nederland heeft Julien van Ostaaijen het urban regime concept gebruikt voor onderzoek naar de veranderingen in het Rotterdamse stadsbestuur in de periode 1998-2008 (J. van Ostaaijen (2010). Aversion and Accomodation. Political Change and Urban Regime Analysis in Dutch Local Government: Rotterdam 1998-2008. Delft: Eburon). Ook interessant: http://www2.ucsc.edu/whorulesamerica/.

37 Zie: E.H. Klijn (2005). Netwerken als perspectief op beleid en uitvoering van beleid. Een overzicht van onderzoek en theorievorming naar netwerken. Beleidswetenschap, 19(4), 32-53.

38 Idem.

39 Zie R.A.W. Rhodes (1997). Understanding Governance: Policy Networks, Governance, Reflexivity and Accountability. Buckingham: Open University Press.

40 Zie bijvoorbeeld: D. Bannink, H. Bosselaar en W. Trommel (eds.) (2013). Crafting Local Welfare Landscapes. Den Haag: Eleven International Publishing; V. Pestoff, T. Brandsen en B. Verschuere (eds.) (2012). New Public Governance, the Third Sector and Co-Production. Abingdon: Routledge; themanummers van het blad Bestuurskunde, zoals jaargang 22 (nrs. 1 en 3), jaargang 21 (nr. 1); maar ook praktijkgerichte studies, te vinden bij bijvoorbeeld kennisinstituut Platform31 (www.platform31.nl).

41 Zie bijvoorbeeld: V. Pestoff, T. Brandsen en B. Verschuere (eds.) (2012). New Public Governance, the Third Sector and Co-Production. Abingdon: Routledge.

42 Zie ook: M. Boogers (2014). Pulling the Strings: An Analysis of Informal Local Power Structures in Three Dutch Cities. Local Government Studies, DOI: 10.1080/ 03003930.2013.841579, 9 January, p. 2. 
43 Vergelijk: M Elsinga en J. van der Schaar (2014). Woningcorporaties: meer dan een eeuw hybriditeit. Bestuurskunde 23(10), 9-17; maar ook de koepelorganisatie Aedes erkent dit, zie: De balans verstoord. Een rapport over de corporatiesector ten behoeve van de Parlementaire Enquête Woningcorporaties, in opdracht van Aedes vereniging van woningcorporaties, Den Haag, mei 2013.

44 J. Feijtel (2014). Huurders mogen verliezen wooncorporatie niet dragen. NRC Handelsblad, 6 maart; Brandsen en Helderman (2009). Woningcorporaties: verbonden vermogen, in: $H$. van Duivenboden, E. van Hout en C. van Montfort (red.). Verbonden Verantwoordelijkheden in het Publieke Domein, pp. 101 - 112; A. Bertram en J.K. Helderman (2008). Wat gaan we doen met de woningcorporatie?, in: F.J.H. Don (red.), Agenda voor de woningmarkt, pp.125-143. F. Fleurke, J. van der Schaar en F. van Wijk (2009). Ontwikkelingspaden voor woningcorporaties. Amsterdam: RIGO.

45 Hun pech is dat daarbij veel is misgegaan, zóveel, dat voor de totale sector geldt dat niet hun commerciële activiteiten de sociale sector financieren - iets wat altijd de bedoeling was, - maar dat het andersom uitpakt de laatste jaren (zie Feijtel 2014 (voetnoot 44), en ook: http://www.gebiedsontwikkeling.nu/artikel/9787-corporatiekoepel-aedes-opnieuw-voor-het-

blok); dat kan in ieder geval met geen mogelijkheid als maatschappelijk of publiek belang worden beschouwd, lijkt me. Dat de overheid, zeker ook de lokale, daar in voorgaande jaren onvoldoende tegenover heeft gezet, moet er overigens in 1 adem bij worden gezegd.

46 De zgn. pluralistische visie op de machtsverdeling.

47 De elitistische visie op de machtsverdeling. Zie voor een recent voorbeeld: Boogers, 2014 (voetnoot 42).

48 De eerdergenoemde in Nederland uitgevoerde stadsstudies (Berveling, Derksen, Lelieveldt, Boogers, voetnoot 27) geven een beeld waarin gemeentelijke actoren zoals de verantwoordelijke wethouder, de burgemeester en een grote ambtelijke dienst meer invloed hebben dan externe spelers. Die laatsten doen wel serieus mee, werken actief samen met de overheid en hebben invloed. Maar dit onderzoek is te weinig, en deels te oud, om zinnige conclusies uit te trekken.

49 Zie bijvoorbeeld: M. Boogers, B. Denters en R. Reussing (2010). Bestuur in beweging: veranderingen in het lokale politiek-bestuurlijke landschap. Bestuurswetenschappen, 64(3), p.11.

50 Een probleem met die bewering is allereerst dat er geen sprake is van 'de overheid'. Dat is ook nooit zo geweest. De overheid is, zo zagen we al eerder, een ingewikkeld samenspel tussen politici, bestuurders en ambtenaren, waarbij de onderlinge interne machtsverhoudingen ook aan verandering onderhevig zijn.

51 Zo stonden kerken en gegoede particulieren in de $19 \mathrm{e}$ eeuw aan de basis van de lokale armenzorg, voordat deze door het gemeentebestuur en later de rijksoverheid werd overgenomen. Ook de woningcorporaties kennen een dergelijke oorsprong (Ministerie van BZK (2006). Scenario's gemeentelijk belastinggebied in relatie tot de bestuurlijke verhoudingen. Den Haag).

52 H.T. Lelieveldt (1999). Wegen naar macht. Politieke participatie en toegang van het maatschappelijk middenveld op lokaal niveau. Amsterdam: Thela Thesis Publishers, pp.14 e.v. Overigens kon die verwevenheid ook betekenen dat politici in woningcorporaties en welzijnsinstellingen de dienst uitmaakten, denk aan het wethouderssocialisme in vorige eeuw.

53 Voor de periode 1996-2005. M. de Vries (2008). Stability despite Reforms: Structural Asymmetries in Dutch Local Policy Networks. Local Government Studies 34(2), 221-243.

54 H. Lensink (2014). Plasterk maakt zich zorgen om integriteit lokaal bestuur. Vrij Nederland, 8 februari.

55 Zie bijvoorbeeld: Ministerie van BZK (2013). Bestuur in samenhang. De bestuurlijke organisatie in Nederland. Den Haag.

56 Onder deze titel zond omroep Gelderland in de aanloop naar de GR-verkiezingen in 2010 een reeks interviews met burgemeesters uit. De burgemeester is ook nog steeds de bekendste figuur van de lokale politiek (R. Frerichs (1999). Aangenaam, de burgemeester, in: Staatscommissie Dualisme en Lokale Politiek, Eindrapport. Alphen aan den Rijn: Samson, 234-242.)

57 W. Derksen en M.L. van der Sande (red.) (1984). De burgemeester, van magistraat tot modern bestuurder. Deventer: Uitgeverij Kluwer. 
58 Idem.

59 Idem.

60 Zie onder meer: W. Derksen en L. Schaap (2010). Lokaal bestuur (zesde druk). Dordrecht: Convoy Uitgevers, pp. 75-91; A. Cachet, N. Karsten en L. Schaap (2010). Van 'sterk merk' naar 'krachtig bestuur'? De toekomst van het burgemeesterschap verkend. Bestuurswetenschappen, 64(6), 327; A.F.A. Korsten (2010). Gedwongen vertrek van burgemeesters. Justitiële Verkenningen, 36(3), 10-30; H. Engels (2012). Tien jaar dualisering: naar een volwassen lokaal bestuur. Bestuurswetenschappen 66(5), 21-31.

61 Volgens diverse deskundigen is zijn positie kwetsbaarder geworden door de grotere invloed die de gemeenteraad heeft op zijn aanstelling, herbenoeming en eventuele ontslag. Hij is meer afhankelijk geworden van het 'humeur en de kwaliteit van de raad', en dat beïnvloedt hem in de eigenstandige uitoefening van zijn werk (zie bijv: Engels, 2012, voetnoot 60).

62 W. Derksen en L. Schaap (2010). Lokaal bestuur (zesde druk). Dordrecht: Convoy Uitgevers, p. 84.

63 De halfslachtige probeersels met een burgemeestersreferendum zijn mislukt, zie ook: R. Reussing (2012). Tien jaar gemeentelijke dualisering: inleiding. Bestuurswetenschappen 66(5), 14-20.

64 T. van de Wijdeven (2012). Doe-democratie. Over actief burgerschap in stadswijken. Delft: Eburon.

65 N. de Boer en J. van der Lans (2011). Burgerkracht. De toekomst van het sociaal werk in Nederland. Den Haag: Raad voor Maatschappelijke Ontwikkeling.

66 Zie hiervoor ook: H. de Bruijn (2013). Kroniek: bespreking van 'Vertrouwen in burgers'. Rapport 88 van de Wetenschappelijke Raad voor het Regeringsbeleid. Bestuurskunde 22(10), 66-69.

67 WRR (2012). Vertrouwen in Burgers, Amsterdam University Press; T. van de Wijdeven (2012). Doe-democratie. Over actief burgerschap in stadswijken. Delft: Eburon.

68 P. van Houwelingen, A. Boele en P. Dekker (2014). Burgermacht op eigen kracht? Een brede verkenning van ontwikkelingen in burgerparticipatie. Den Haag: SCP.

69 Idem.

70 In de Scandinavische landen bestaat die feitelijk al veel langer, daar heeft de verzorgingsstaat in feite lokaal vorm gekregen na WW-II. Zie: L.E. Rose and K. Stahlberg (2005). The Nordic Countries: still the 'promised land'? , in: B. Denters and L. E. Rose (eds.) (2005). Comparing Local Governance. Trends and Developments. Basingstoke: Palgrave MacMillan, p.83; Rose (1999). Citizen (re)orientations to the Welfare State: From Public to Private Citizens? In: J. Bussemaker (ed.) Citizenship and Welfare State Reform in Europe. London: Routledge.

71 K. Putters (2013). Het smalle pad van verzorgingsstaat naar verzorgingsstad, lezing De Balie, 23 mei. De term 'verzorgingsstad' is al eerder, in 2006, gebruikt door Jos van der Lans.

72 J. Moerkamp, 'Vrijstaat Keppel'. Binnenlands Bestuur, 24 mei 2013.

73 Idem.

74 Burgermacht die vragen oproept: welke verschijningsvormen van dit soort burgermacht zien we? Hoe gaat dat verder, is het een trend? Zien we het elders ook, bieden andere landen lessen in dit opzicht? Is het diplomademocratie (M. Bovens en A. Wille (2011). Diplomademocratie: Over de spanning tussen meritocratie en democratie. Amsterdam: Uitgeverij Bert Bakker), dat wil zeggen: zijn de initiatiefnemers per definitie hoogopgeleide burgers? En daarnaast roept het natuurlijk vragen op over de rol van de overheid: wat doet die ermee, wat móet die ermee, wat kán die ermee?

75 Zie K. Peters (2007). Het opgeblazen bestuur. Een kritische kijk op de provincie. Amsterdam: Uitgeverij Boom.

76 Een actueel voorbeeld is de arbeidsmigratie uit Polen, Roemenië en Bulgarije en de gevolgen daarvan voor de steden.

77 Of central-local relations, zoals het heet in de internationale literatuur.

78 Vergelijk: K. Peters (2006). Impuls voor de lokale democratie? De casus van de WMO, in: E.K. Schrijvers, P.L. Meurs, G.H. de Vries (red.). Leren van de praktijk. Gebruik van lokale kennis en ervaring voor beleid. Den Haag/Amsterdam: Wetenschappelijke Raad voor het Regeringsbeleid/Amsterdam University Press. En ook: N. de Boer en J. van der Lans (2014). Burger dwingt lokale politiek tot deliberatie. Beleid en Maatschappij 41(1), 74-79. 
79 VNG-commissie Gemeentewet en Grondwet (commissie-Van Aartsen) (2007). De eerste overheid. Den Haag: VNG. Zie ook: M. Boogers en B. Denters (2013). Twee perspectieven op de eerste overheid. Bestuurskunde 22(3), 5-14.

80 Vgl: W. Derksen (2014). Het grote misverstand van de lokale politiek. 4 maart: http://www.wimderksen.com/?p=52878.

81 Pogingen van vakgenoten om de beleidsvrijheid van gemeenten op diverse taakgebieden te meten, een aantal jaren geleden, leidden tot de onbevredigende conclusie dat er geen algemeen beeld te geven is: T. Brandsen, L.J. de Graaf, F. Hendriks, E.D. van den Munckhof, D. Hanemaayer, P. Kalders, en J. Scheeren (2006). Zichtbaar maken van gemeentelijke beleidsvrijheid. Den Haag: Ministerie van Binnenlandse Zaken.

82 Zie bijvoorbeeld: L. Schaap (2012). Decentrale autonomie? Rapportage ter voorbereiding op het onderzoek van de Raad van Europa naar de staat van de decentrale autonomie in Nederland, rapportage in opdracht van VNG en IPO. Tilburg: Universiteit Tilburg.

83 Idem.

84 Zie onder meer: Raad van State (2013). Het kán beter. Interbestuurlijke verhoudingen opnieuw beschouwd. Den Haag; K. Veldhuijzen (2013) No representation without taxation. Idee 34(3), 1417; L. Schaap (2012). Decentrale autonomie? Rapportage ter voorbereiding op het onderzoek van de Raad van Europa naar de staat van de decentrale autonomie in Nederland, rapportage in opdracht van VNG en IPO. Tilburg: Universiteit Tilburg.

85 Zie: B. Denters and Lawrence E. Rose (eds.)(2005). Comparing Local Governance. Trends and Developments. Basingstoke: Palgrave MacMillan; J. Loughlin, F. Hendriks and A. Lidström (2011). The Oxford Handbook of Local and Regional Democracy in Europe. Oxford: Oxford University Press.

86 'Wat blijft er over voor Den Haag?', vraagt Kim Putters zich af in de eerdergenoemde lezing (zie noot 71).

87 K. Veldhuijzen (2013) No representation without taxation. Idee 34(3), 14-17.

88 De term 'The Local State' (of: 'der Lokale Staat') is met name in de jaren '70 gebruikt voor maatschappijkritische publicaties, over rebellie van linkse gemeentebestuurders tegen de kapitalistische of neoliberale staat. De lokale staat wordt dan de tegenstander of uitdager van de nationale staat, een 'eigen lokale staat' dus. Zie bijvoorbeeld: P. Corrigan (1979) The Local State: the Struggle for Democracy. Marxism Today, July, 203-209. 